\title{
HABITAT PREFERENCE OF DIFFERENT SIZE CLASSES OF AUSTROPOTAMOBIUS PALLIPES IN AN IRISH RIVER
}

\author{
A. DEMERS (1), J.D. REYNOLDS (2), A. CIONI (3)
}

University of Dublin, Zoology Department, Trinity College, Dublin 2, Ireland.

(1) bydemers@yahoo.fr

(2) jrynolds@tcd.ie

(3) Astra-cioni@hotmail.com

Reçu septembre 2003

Accepté le 3 mars 2004

Received September 2003

Accepted March 3, 2004

\begin{abstract}
Juvenile and immature crayfish are more difficult to find than adults and in consequence rather little is known about their habitat preferences. Smaller crayfish are able to inhabit different areas within the stream compared to adult crayfish. Whereas adult crayfish occur under stones and cobble in the river, juveniles and small individuals may be found along the margins, among rootlets and vegetation. A survey was carried at two sites in the Liffey catchment (Ireland) to assess habitat preference of crayfish according to size. A Surber sampler was used to collect crayfish in five types of habitat present at these sites. Each site presented a different distribution of crayfish amongst the habitat types. At Kilbride bridge, crayfish preferred cobble to pebbles and submerged and emergent macrophytes, while at Carragh bridge, crayfish were more dispersed throughout the habitat types. At both sites, juveniles and one year old crayfish were found in a variety of habitat types, whereas adults were only found in cobble and pebbles. The discrepancy in crayfish densities between the two sites can probably be explained by characteristics, such as depth and flow rate, that were not taken into account in the categorisation of the habitats.
\end{abstract}

Key-words: Austropotamobius pallipes, juvenile, habitat.

\section{HABITAT PRÉFÉRENTIEL D'AUSTROPOTAMOBIUS PALLIPES SELON LA TAILLE DANS UN RIVIÈRE EN IRLANDE}

\section{RÉSUMÉ}

L'utilisation de l'habitat par les écrevisses juvéniles est relativement peu connue en raison de leur petite taille les rendant plus difficiles à échantillonner que les adultes. Les écrevisses de petite taille peuvent habiter des habitats plus diversifiés que les adultes. Les adultes trouvent refuge sous roches et cailloux alors que les écrevisses plus petites peuvent être trouvées également le long des berges, dans les radicelles ou dans la végétation aquatique. Cette étude a été menée sur deux sites dans le bassin du fleuve Liffey dans le but de déterminer la préférence en matière d'habitat des écrevisses à pattes blanches en fonction de leur taille. Un filet Surber a été utilisé pour l'échantillonnage des écrevisses dans cinq types de substrats. A Kilbride bridge, les écrevisses ont surtout été 
retrouvées dans les roches, délaissant la végétation alors qu'à Carragh bridge elles étaient dispersées dans tous les types d'habitat. On retrouve les écrevisses de plus petite taille dans tous les types de substrats, tandis que les adultes se concentrent dans les roches et le gravier. Les deux sites présentaient des densités d'écrevisses différentes qui pourraient être expliquées par des variations du courant ou la profondeur.

Mots-clés : Austropotamobius pallipes, juvénile, habitat.

\section{INTRODUCTION}

Juvenile and immature crayfish are more difficult to find than larger individuals and in consequence rather little is known about them in terms of habitat preference. Each site within a river and between rivers may present individual characteristics and offer crayfish several habitats. Smaller crayfish can inhabit different areas within the stream compared to larger crayfish. Whereas adult crayfish occur under stones and cobble in the river, smaller individuals may be found along the margins, among rootlets and vegetation (SMITH et al., 1996; REYJOL and ROQUEPLO, 2002). REYJOL and ROQUEPLO (2002) found that, although certain habitats such as rocks and cobble were inhabited by all size classes, other habitats, such as pebbles and vegetation, were colonised almost exclusively by the smaller crayfish.

Austropotamobius pallipes has been studied in a variety of habitats in many countries. Because of the interest generated by this large invertebrate, several methods have been used to catch crayfish, including baited traps, stone turning by hand, kicksampling and diving. All these methods have positive and negative characteristics and will generally target crayfish of different sizes. Baited traps are known to catch almost exclusively adults (O'KEEFFE, 1986; MATTHEWS and REYNOLDS, 1995; BYRNE et al., 1999; GRANDJEAN et al., 2000). Stone turning, Surber samplers and kick sampling will indicate crayfish presence, but will underestimate the more mobile adults. These methods, however, can be used to sample smaller individuals, namely juveniles and immatures, which are not found using traps (SMITH et al., 1996; BYRNE et al., 1999; GARCIAARBERAS and RALLO, 2000; NEVEU, 2000). The present study set out to investigate habitat preferences of smaller sized $A$. pallipes at two different river sites.

\section{MATERIALS AND METHODS}

\section{Study area}

Two sites in the Liffey catchment (Ireland) were chosen for this study: Kilbride bridge (Co. Wicklow, National Grid Reference O027 180) and Carragh bridge (Co. Kildare, NGR N854 207). Both sites were chosen because of their accessibility and suitable depth for Surber sampling.

Kilbride bridge is on the Brittas River, a tributary of the Liffey which joins the main channel $3.5 \mathrm{~km}$ upstream of the Pollaphuca reservoir. The river at this site is 1 to 2 metres wide and $5 \mathrm{~cm}$ to $50 \mathrm{~cm}$ in depth. Here, the river first flows straight, bordered by grasses, with a substrate of pebbles and sand. It then goes through a bend and becomes shallower with riffles over pebbles and cobble. The sampling area covered approximately $20 \mathrm{~m}^{2}$. Four different habitats were identified for crayfish at this site: cobble ( $>10 \mathrm{~cm}$ diameter), pebbles ( $<5 \mathrm{~cm}$ diameter), emergent macrophytes, and submerged macrophytes.

The second site, Carragh bridge is on the mainstream Liffey approximately $75 \mathrm{~km}$ from the source. The river there is wide $(25 \mathrm{~m})$ with varying depth, but can generally be waded through. The sampling was concentrated in one area of $30 \mathrm{~m}^{2}$, close to the bank, where riffles alternate with glides and where in-stream emergent vegetation was present. 
Five habitats were identified at this site: cobble $(>10 \mathrm{~cm}$ diameter), pebbles $(<10 \mathrm{~cm}$ diameter), emergent macrophytes, submerged macrophytes, and loose leaf litter packs. In this case, the substrate called "pebbles" consisted mostly of rocks less than $5 \mathrm{~cm}$ in diameter, as at Kilbride, but also included larger rocks (up to $10 \mathrm{~cm}$ ).

\section{Sampling Methods}

Both sites were visited on three occasions, on 7 and 26 August and 2 September 2002. Depth was measured at each habitat type with a metre stick and flow was estimated visually into three qualitative categories: fast (strong riffle), medium (slow riffle), slow (glide). All habitat types were sampled on these dates. Values of surface area covered by each substrate type were estimated visually. Sand was not sampled because it was scarce and not considered as suitable for crayfish.

A Surber sampler was used to sample crayfish. The sampler is made of a square metal frame enclosing an area of $0.09 \mathrm{~m}^{2}$. Downstream, an attached $1 \mathrm{~mm}$ mesh size net flows in the current at a right angle to the frame in order to catch anything drifting in the water. The quadrat was placed on the substrate, the substrate was then thoroughly disturbed and washed in the current and all invertebrates, including crayfish, were caught in the net.

When possible, ten Surber samples were taken for each type of habitat covering a total surface area of $0.9 \mathrm{~m}^{2}$ in which crayfish might be caught. Within a habitat, samples were chosen randomly, except when the total available surface area did not permit it. In total, per day of sampling, 37 samples were taken at Brittas and 43 at Carragh. Two invertebrate samples (out of the ten taken) were preserved at each habitat type for further identification. All crayfish were measured using callipers (carapace length to nearest $0.5 \mathrm{~mm}$ ) and sexed when possible. They were then released. Crayfish densities were calculated per metre squared.

\section{RESULTS}

\section{Habitats}

Table I give an estimated percentage of the sampling surface area covered by each substrate types at each site. At Kilbride bridge, cobble was predominant whereas at Carragh, cobble, submerged vegetation and pebbles covered most of the riverbed. In terms of surface area covered by each substrate type, the two sites are not significantly different $(p=0.4)$.

Water depth and flow was different for every substrate type and between the two sites (Table II). Cobble and pebbles at Carragh bridge were generally found at greater depths than at Kilbride bridge. Water flowed at a higher velocity over submerged vegetation at Kilbride bridge than at Carragh. Water was almost stationary over the leaf litter at the latter site and flow was thus classified as "very slow".

Both sites presented similar macroinvertebrate communities in terms of species composition and abundance (DEMERS, 2003), but some habitats had a more abundant invertebrate fauna according to the Surber samples (Table III). Pebbles at Kilbride bridge and cobble at Carragh bridge had fewest invertebrates, while macrophytes (emergent and submerged) had the most macroinvertebrates per $\mathrm{m}^{2}$.

\section{Crayfish density}

Crayfish density measured with the Surber sampler was generally higher at Carragh than at Kilbride. Average density at Kilbride bridge was 3.3 crayfish per $\mathrm{m}^{2}$ (standard 
Table I

Estimated percentage and surface area covered by each substrate types at each site. Total surface areas at Kilbride and Carragh were $20 \mathrm{~m}^{2}$ and $30 \mathrm{~m}^{2}$ respectively.

Tableau I

Pourcentage et aire approximatifs de la surface d'échantillonnage couverte par chaque type de substrat à chaque site. L'aire totale d'échantillonnage à Kilbride et à Carragh est de $20 \mathrm{~m}^{2}$ et $30 \mathrm{~m}^{2}$ respectivement.

\begin{tabular}{|l|c|c|c|c|}
\hline \multirow{2}{*}{ Substrate } & \multicolumn{2}{|c|}{ Kilbride } & \multicolumn{2}{c|}{ Carragh } \\
\cline { 2 - 5 } & percentage & area & percentage & area \\
\hline Cobble & $25 \%$ & $5 \mathrm{~m}^{2}$ & $40 \%$ & $12 \mathrm{~m}^{2}$ \\
\hline Pebble & $50 \%$ & $10 \mathrm{~m}^{2}$ & $20 \%$ & $6 \mathrm{~m}^{2}$ \\
\hline Sumerged vegetation & $10 \%$ & $2 \mathrm{~m}^{2}$ & $30 \%$ & $9 \mathrm{~m}^{2}$ \\
\hline Emergent vegetation & $10 \%$ & $2 \mathrm{~m}^{2}$ & $5 \%$ & $1.5 \mathrm{~m}^{2}$ \\
\hline Leaf litter & $0 \%$ & $1 \mathrm{~m}^{2}$ & $3 \%$ & $1 \mathrm{~m}^{2}$ \\
\hline Sand & $5 \%$ & $0.5 \mathrm{~m}^{2}$ & $1 \%$ & $0.5 \mathrm{~m}^{2}$ \\
\hline
\end{tabular}

Table II

Depth and flow rate according to substrate at both sites.

Tableau II

Profondeur et vitesse du courant en fonction du type d'habitat à chaque site.

\begin{tabular}{|l|c|c|c|c|}
\hline Site & \multicolumn{2}{|c|}{ Kilbride bridge } & \multicolumn{2}{c|}{ Carragh bridge } \\
\hline Substrate & Depth range & Flow rate & Depth range & Flow rate \\
\hline Cobble & $20-25 \mathrm{~cm}$ & Fast & $25-40 \mathrm{~cm}$ & Fast \\
\hline Pebbles & $5-20 \mathrm{~cm}$ & Fast & $15-20 \mathrm{~cm}$ & Fast \\
\hline Submerged vegetation & $5-15 \mathrm{~cm}$ & Fast & $5-10 \mathrm{~cm}$ & Medium \\
\hline Emergent vegetation & $5-25 \mathrm{~cm}$ & Slow & $5-10 \mathrm{~cm}$ & Slow \\
\hline Leaf litter & - & - & $10 \mathrm{~cm}$ & Very slow \\
\hline
\end{tabular}

Table III

Average number of invertebrates collected with a Surber sampler, over a surface area of $0.09 \mathrm{~m}^{2}$. Cobble are $>10 \mathrm{~cm}$ diameter; pebbles are $<10 \mathrm{~cm}$; "emergent" refers to emergent macrophytes; "submerged" refers to submerged macrophyte.

Tableau III

Nombre moyen d'invertébrés échantillonés avec un "Surber sampler", sur une surface de $0,09 \mathrm{~m}^{2}$. "Cobble" ont $>10 \mathrm{~cm}$ de diamètre ; "pebbles" ont $<10 \mathrm{~cm}$ de diamètre ; "emergent" indique la végétation émergeante ; "submerged" indique la végétation entièrement submergée.

\begin{tabular}{|l|c|c|c|c|c|}
\hline & \multicolumn{5}{|c|}{ Habitat } \\
\hline Site & Cobble & Pebbles & Emergent & Submerged & Leaf litter \\
\hline Kilbride & 293 & 132 & 328 & 243 & - \\
\hline Carragh & 64 & 152 & 205 & 261 & 163 \\
\hline
\end{tabular}


deviation 0.3) while mean density at Carragh bridge was 5.1 crayfish per $\mathrm{m}^{2}$ (standard deviation 1.9). These densities are for all substrate types combined. The total surface area sampled each day for Kilbride bridge and Carragh bridge was $3.96 \mathrm{~m}^{2}$ and $3.33 \mathrm{~m}^{2}$ respectively.

Crayfish densities varied according to substrate type. However, the two sites presented a different pattern of crayfish distribution within the river. At Kilbride bridge, in terms of both densities and total number caught, most crayfish were found in the cobble, with a few crayfish occurring in the vegetation (Table IV). By contrast, at Carragh bridge, crayfish were more evenly distributed throughout the river. Crayfish at Carragh were most dense in the leaf litter, but were found in similar numbers in the submerged vegetation, pebbles and cobble (Table IV).

\section{Table IV}

Total number of crayfish caught, total area of sampling $\left(\mathrm{m}^{2}\right)$ and mean density (crayfish $/ \mathrm{m}^{2}$ ) over three days according to substrate type. Cobble are $>10 \mathrm{~cm}$ diameter; pebbles are $<10 \mathrm{~cm}$; "emergent" refers to emergent macrophytes; "submerged" refers to submerged macrophyte.

\section{Tableau IV}

Nombre total d'écrevisses capturées, aire d'échantillonnage totale $\left(\mathrm{m}^{2}\right)$ et densité moyenne (écrevisses $/ \mathrm{m}^{2}$ ) sur trois jours en fonction du type d'habitat. "Cobble" ont > $10 \mathrm{~cm}$ de diamètre ; "pebbles" ont < $10 \mathrm{~cm}$ de diamètre ; "emergent" désigne la végétation émergeante; "submerged" désigne la végétation entièrement submergée.

\begin{tabular}{|c|c|c|c|c|c|c|}
\hline \multirow{2}{*}{ Site } & \multirow{2}{*}{ Data } & \multicolumn{5}{|c|}{ Substrate type } \\
\cline { 3 - 7 } & & Cobble & Pebbles & Emergent & Submerged & Leaf litter \\
\hline \multirow{3}{*}{ Kilbride } & Number & 34 & 0 & 2 & 1 & - \\
\cline { 2 - 7 } & Area & 2.7 & 2.7 & 2.7 & 1.89 & - \\
\cline { 2 - 7 } & Density & 12.6 & 0.0 & 0.7 & 0.5 & - \\
\hline \multirow{3}{*}{ Carragh } & Number & 14 & 16 & 3 & 17 & 10 \\
\cline { 2 - 7 } & Area & 2.7 & 2.7 & 2.7 & 2.7 & 0.81 \\
\cline { 2 - 7 } & Density & 5.2 & 5.9 & 1.1 & 6.3 & 12.4 \\
\hline
\end{tabular}

The Surber sampler caught mostly juvenile (young of the year) and immature crayfish (Figure 1). Two peaks representing the young of the year (in August, carapace length of 5 to $15 \mathrm{~mm}$ ) and one-year-old crayfish (in August, carapace length of 15 to $20 \mathrm{~mm}$ ) are clearly shown in Figure 1 for Carragh bridge. One-year-old crayfish were not as numerous at Kilbride bridge. A few larger crayfish (>20 mm CL) were also caught. Crayfish between 20 and $25 \mathrm{~mm}$ carapace length are 2 or 3 years old and would probably have matured in autumn 2002. Crayfish larger than $25 \mathrm{~mm} \mathrm{CL}$ are considered sexually mature.

Crayfish of different size were not dispersed equally throughout the different substrate types. At Kilbride bridge, juveniles (young of the year, less than $15 \mathrm{~mm} \mathrm{CL}$ ) were found mostly in cobble, but also in emergent and submerged vegetation (Figure 2). At Carragh bridge, young of the year and one-year-old crayfish (between $15 \mathrm{~mm}$ and $20 \mathrm{~mm} \mathrm{CL}$ ) were found in all habitats (Figure 3), while older crayfish (more than $20 \mathrm{~mm} \mathrm{CL}$ ) were not found in the vegetation and leaf litter. 


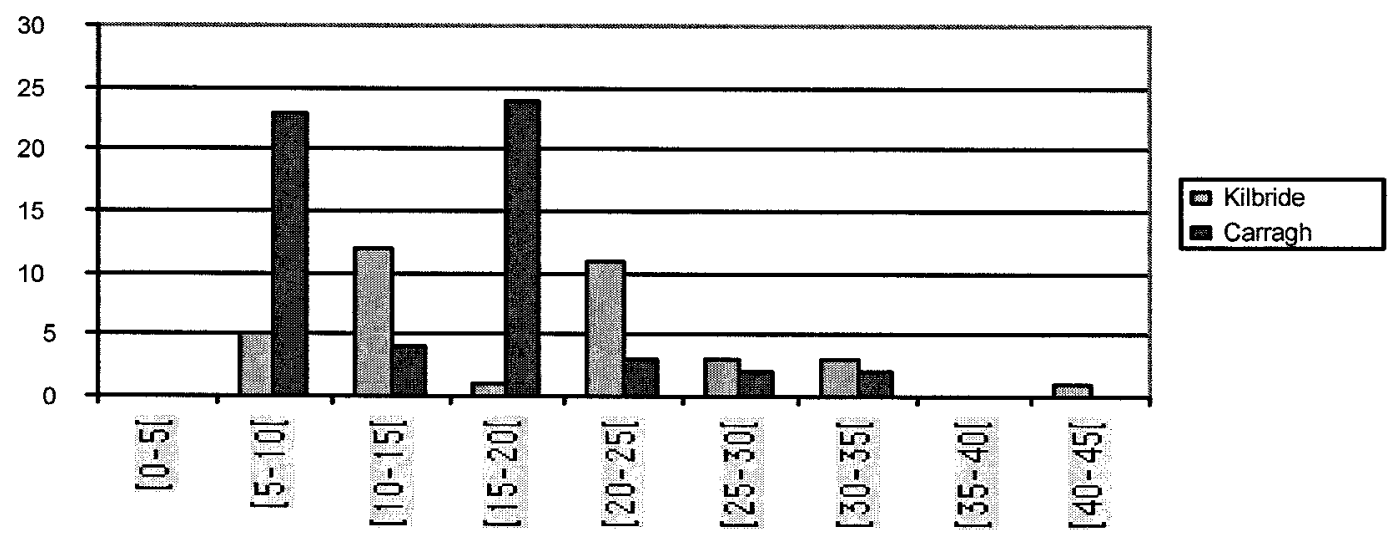

Figure 1

Carapace length $(\mathrm{mm})$ distribution of all crayfish caught using a Surber sampler at Carragh and Kilbride bridges.

Figure 1

Distribution de la longueur de la carapace $(\mathrm{mm})$ des écrevisses attrapées avec un filet Surber aux deux sites.

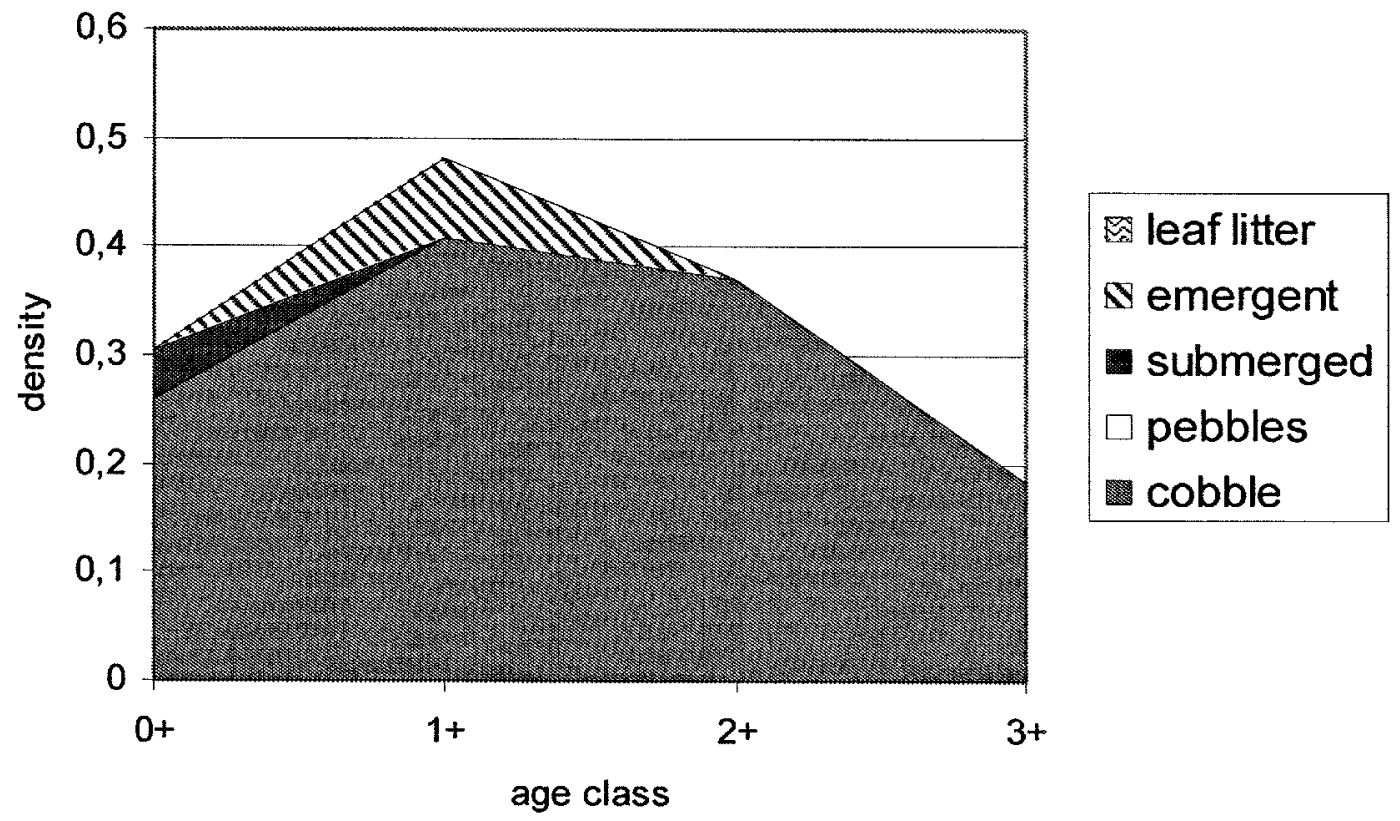

Figure 2

Density per $\mathrm{m}^{2}$ of crayfish according to age and substrate type at Kilbride bridge.

Figure 2

Densité par $\mathrm{m}^{2}$ des écrevisses selon leur âge et le type de substrat à Kilbride bridge. 


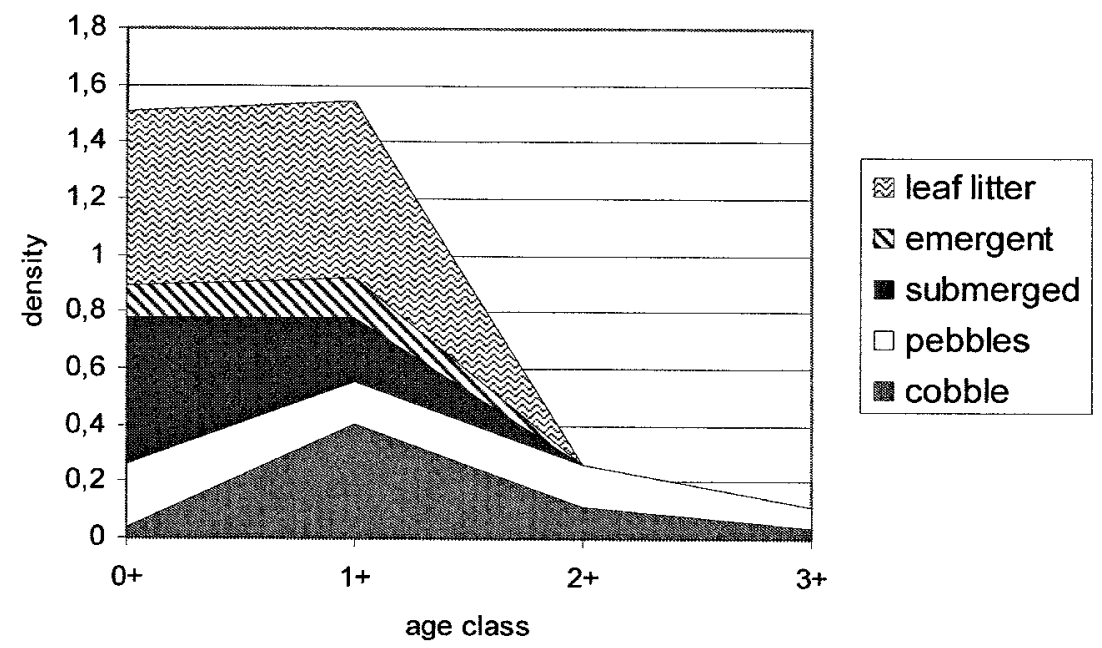

Figure 3

Density per $\mathrm{m}^{2}$ of crayfish according to age and substrate type at Carragh bridge.

\section{Figure 3}

Densité par $\mathrm{m}^{2}$ des écrevisses selon leur âge et le type de substrat à Carragh bridge.

\section{DISCUSSION}

The habitat at Carragh bridge was more structurally complex than at Kilbride bridge and this might explain the higher density of crayfish, 5.1 compared to 3.3 (also a higher standard deviation, 1.9 compared to 0.3 ). At Kilbride, crayfish were mostly found in cobble, with very low densities found in macrophyte habitats, while at Carragh, crayfish were found in all habitats. This preference for cobble at Kilbride bridge might be explained by the small size of the pebbles (generally less than $5 \mathrm{~cm}$ diameter) at this site and by the scarcity of submerged vegetation, a feature of high velocity water flows. The pebble substrate at Kilbride is probably unstable and the interstices between them offer very little shelter, even to juvenile crayfish. The white-clawed crayfish does not live in rivers with very high flow rates (FOSTER, 1995). Macrophytes, which can offer shelter and probably abundant food supply, occurred at Kilbride bridge but were exposed to high flow rates and did not harbour many crayfish. Crayfish were found in good numbers in the submerged macrophytes at Carragh bridge, which were found in slow moving current. Flow can vary if pools, riffles, bends and obstacles are present in the channel. Water velocity can therefore affect the potential of different types of substrate for holding crayfish.

Crayfish at Carragh bridge were more dispersed throughout the habitats. Submerged macrophytes, pebbles and cobble harboured similar density of crayfish. Emergent macrophytes did not yield as many crayfish as the other substrates but this finding might be owing to the sampling method. The Surber sampler is designed to catch disturbed invertebrates drifting in the current. At both sites, the emergent vegetation was found along the banks or in raised "islands" in the river and the water flow was always slow. This possibly contributed to the underestimation of crayfish density in the emergent macrophytes. On the other hand, the slow flow rate of this habitat entails accumulation of silt and perhaps lower dissolved oxygen, which might impact on crayfish survival in this habitat. The highest density of crayfish at Carragh bridge was in the leaf litter packs. Leaf litter offers good shelter for crayfish, particularly small individuals, and for other 
invertebrates which are food items of crayfish. The decaying plant matter can also provide food. However, dissolved oxygen in the leaf litter might be low owing to slow current and decomposition.

This investigation also points towards a preferential use of the different habitats by crayfish depending on their size. Although the Surber sampler is best suited to catch juvenile and immature crayfish, adult crayfish were also caught during sampling. All crayfish two years or older caught at Kilbride bridge were found in cobble. At Carragh bridge, the larger crayfish were found in cobble and in pebbles. Juvenile and one-year-old crayfish were found in a diversity of habitats, including sharing habitats such as cobble with adult crayfish. REYJOL and ROQUEPLO (2002) found areas within rivers that could be dominated by juveniles, such as vegetation and pebbles, while others harboured crayfish of all sizes (cobble and banks).

Although in the present study few crayfish were caught in total, the results suggest a partial segregation of habitat use according to crayfish size. Authors point to intraspecific competition in different species of crayfish, whereby adults will exclude juveniles from preferred habitats (e.g. STEIN, 1977; LODGE and HILL, 1994). Adult crayfish are thought to reduce growth and survival of juvenile crayfish by competing for shelter and by direct predation, thus inducing smaller crayfish to seek shelter away from adults and cutting the amount of time spent feeding (MOMOT, 1993; BLAKE et al., 1994; LODGE and HILL, 1994). This could explain in part why juveniles and smaller crayfish are found in a wider variety of habitats than adults. Larger crayfish would preferentially choose large shelter (FOSTER, 1993), which in the two sites visited is found among cobble and, to a certain extent at Carragh, in pebbles. The boulder habitats were heterogeneous at both sites and were composed of rocks of diverse sizes and shapes, which offered shelter of varying proportions. This situation would favour the observed co-habitation of adults and younger crayfish.

Observations on the impact of predators on crayfish survival and growth suggest that juvenile crayfish, which are vulnerable to predatory fish, will inhabit shallow water where they are less susceptible to such predation (ENGLUND, 1999; ENGLUND and KRUPA, 2000). Adults will prefer deeper waters to escape terrestrial predators, such as otters and minks, which represent a greater danger to a large crayfish. Adult crayfish can avoid predation by fish, even when exposed (STEIN and MAGNUSON, 1976; STEIN, 1977; DORN and MITTELBACH, 1999). This could possibly explain why adults were not found in the vegetation and leaf litter (which were generally shallow) at Carragh bridge, although depth throughout the river at this site varies little. Otters, which include crayfish in their diet, are known to live at both sites (HAMILTON and ROCHFORD, 2000) and crayfish remains were found in otter spraints at Carragh bridge (E. HOLMES, pers. comm.). Rocks and cobble probably offer more secure shelter from otters to a large crayfish.

BLAKE et al. (1994) found that, when kept with fish and adult crayfish, juvenile Pacifastacus leniusculus will have higher growth and survival rates when weed is available as shelter. KERSHNER and LODGE (1995) found that, in the field, Orconectes rusticus juveniles had lower mortality in macrophytes and cobbles than in sand. At Carragh bridge, juvenile and one-year-old crayfish would find shelter in the plentiful macrophyte, but at Kilbride bridge, macrophytes were less abundant and found in high velocity current, which could explain why most juveniles were found in cobble. The lack of alternative habitats where younger crayfish can take refuge, away from adults, may impact on the recruitment of juveniles at Kilbride bridge.

Shelter availability is without a doubt a very important factor in determining the abundance of a crayfish population. Hides will protect crayfish from predators such as fish and otters, but also from other crayfish in times of moult. Cannibalism is thought to be a common occurrence amongst crayfish, although it has rarely been precisely studied (BLAKE et al., 1994). Aggressive behaviour is a major constraint in communal 
rearing systems, used for commercial or restocking purposes (MATTHEWS, 1992; SÁEZROYUELA et al., 1995). Moulting in juveniles is less synchronised than in adults (LOWERY, 1988; TAUGBØL and SKURDAL, 1992; SÁEZ-ROYUELA et al., 2001), which would make small crayfish even more susceptible to predation from conspecifics and stresses the need for suitable shelter.

Nevertheless, other factors will interact with refuge availability to determine the abundance of crayfish at a particular site (BLAKE et al., 1994; LODGE and HILL, 1994). Environmental parameters such as $\mathrm{pH}$, hardness or temperature, which are significant factors in terms of crayfish survival and growth, would not be limiting at the two sites included in this study. Both sites were in the same catchment, with similar soil type and water chemistry. Food availability also plays a substantial role in crayfish survival. The white-clawed crayfish is an omnivore, which will eat more invertebrates during the first years of its life and become more herbivore and detritivore with time (REYNOLDS, 1979; MOMOT, 1995). The macroinvertebrate fauna varies little between microhabitats within a site in terms of species composition. The different habitats sampled presented similar invertebrate composition, dominated by dipterans, mayflies and crustaceans in the case of Kilbride. Crayfish will have a measurable impact on large, less mobile benthic invertebrates (MATTHEWS et al., 1993; NYSTRÖM, 1999), which in this case would be mostly dipteran larvae, found throughout the habitats at both Kilbride and Carragh bridge. Therefore, the availability of a particular food item should not be a factor when choosing a substrate.

To conclude, $A$. pallipes can occupy a variety of habitats but this study suggests a preference of certain substrates depending on the size of the individual and certain environmental characteristics of the habitat. Certain types of habitat, such as leaf litter and vegetation, provide shelter for juvenile and immature crayfish, while other substrates, such as cobble and pebbles, will contain crayfish of all sizes. A combination of factors (flow, depth, shelter size, and invertebrate fauna) will interact to provide an optimum habitat for juvenile crayfish. The small overall number of crayfish caught during this study prevents a better understanding of the habitat use of crayfish according to size. A larger number of samples or sampling sites would be necessary to obtain a clearer picture.

\section{ACKNOWLEDGEMENTS}

Many thanks to Peter Stafford and Alison Boyce for their help with the equipment and in the field.

\section{REFERENCES}

BLAKE M., NYSTRÖM P., HART P., 1994. The effect of weed cover on juvenile signal crayfish (Pacifastascus leniusculus Dana) exposed to adult crayfish and nonpredatory. Annales Zoologici Fennici, 31, 297-306.

BYRNE C.F., LYNCH J.M., BRACKEN J.J., 1999. A sampling strategy for stream populations of white-clawed crayfish, Austropotamobius pallipes (Lereboullet) (Crustacea, Astacidae). Biology and Environment: Proceedings of the Royal Irish Academy, 99B(2), 89-94.

DEMERS A., 2003. The water quality requirements of the white-clawed crayfish, Austropotamobius pallipes Lereboullet. Ph.D. Thesis, department of Zoology, University of Dublin, $225 \mathrm{p}$.

DORN N.J., MITTELBACH G.G., 1999. More than predator and prey: a review of interactions between fish and crayfish. Vie et Milieu, 49(4), 229-237. 
ENGLUND G., 1999. Effects of fish on the local abundance of crayfish in stream pools. Oikos, 87, 48-56.

ENGLUND G., KRUPA J.J., 2000. Habitat use by crayfish in stream pools: influence of predators, depth and body size. Freshwater Biology, 43, 75-83.

FOSTER J., 1993. The relationship between refuge size and body size in the crayfish Austropotamobius pallipes (Lereboullet). Freshwater Crayfish, 9, 345-349.

FOSTER J., 1995. Factors influencing the distribution and abundance of the crayfish Austropotamobius pallipes (Lereboullet) in Wales and the Marches, UK. Freshwater Crayfish, 8, 78-93.

GARCIA-ARBERAS L., RALLO A., 2000. Survival of natural populations of Austropotamobius pallipes in rivers in Bizkaia, Basque Country (North Iberian Peninsula). Bull. Fr. Pêche Piscic., 356(1), 17-30.

GRANDJEAN F., CORNUAULT B., ARCHAMBAULT S., BRAMARD M., OTREBSKY G., 2000. Life history and population biology of the white-clawed crayfish, Austropotamobius pallipes, in a brook from the Poitou-Charentes region (France). Bull. Fr. Pêche Piscic., 356(1), 55-70.

HAMILTON G. and ROCHFORD J., 2000. The distribution of the otter Lutra lutra in relation to water quality and other factors in three hydrometric areas in the east of Ireland. Unpublished report to the Heritage Council, Ireland. Contract number WLD/2000/ 22, Dublin, $31 \mathrm{p}$.

KERSHNER, M.W., LODGE, D.M. 1995. Effects of littoral habitat and fish predation on the distribution of an exotic crayfish, Orconectes rusticus. Journal of the North American Benthological Society, 14(3), 414-422.

LODGE, D.M., HILL, A. 1994. Factors governing species composition, population size, and productivity of cool-water crayfishes. Nordic Journal of Freshwater Resources, 69, 111-136.

LOWERY, R.S. 1988. Growth, moulting and reproduction. In: D.M. Holdich and R.S. Lowery (eds). Freshwater crayfish biology, management and exploitation. Croom Helm. London, pp. 83-113.

MATTHEWS M.A., 1992. Reproduction, growth and aquaculture potential of the freshwater crayfish Austropotamobius pallipes (Lereboullet). PhD thesis. Zoology Department. University of Dublin, $142 \mathrm{p}$.

MATTHEWS M.A., REYNOLDS J.D., 1995. A population study of the white-clawed crayfish Austropotamobius pallipes (Lereboullet) in an irish reservoir. Biology and Environment: Proceedings of the Royal Irish Academy, 95B(2), 99-109.

MATTHEWS M.A., REYNOLDS J.D., KEATINGE M.J., 1993. Macrophyte reduction and benthic community alteration by the crayfish, Austropotamobius pallipes (Lereboullet). Freshwater Crayfish, 9, 289-299.

MOMOT W.T., 1993. The role of exploitation in altering the processes regulating crayfish populations. Freshwater Crayfish, 9, 101-117.

MOMOT W.T., 1995. Redefining the role of crayfish in aquatic ecosystems. Reviews in Fisheries Science, 3, 33-63.

NEVEU A., 2000. Étude des populations d'Austropotamobius pallipes (Crustacea, Astacidae) dans un ruisseau forestier de Normandie. II. Répartition en fonction des 
habitats: stabilité et variabilité au cours de cinq années. Bull. Fr. Pêche Piscic., 356(1), 99-122.

NYSTRÖM P., 1999. Ecological impact of introduced and native crayfish on freshwater communities: European perspectives. In: F. Gherardi and D.M. Holdich (Eds). Crayfish in Europe as alien species: How to make the best of a bad situation? A.A. Balkema, Rotterdam, pp. 63-85.

O'KEEFFE C., 1986. The ecology of two populations of freshwater crayfish Austropotamobius pallipes (Lereboullet) in Ireland. Ph.D. Thesis, department of Zoology, University of Dublin, $254 \mathrm{p}$.

REYJOL Y., ROQUEPLO C., 2002. Preferential habitat analysis of white-clawed crayfish, notably juveniles, in three brooks of Corrèze, France. Bull. Fr. Pêche Piscic., 367(4), 741-762.

REYNOLDS J.D., 1979. Crayfish ecology in Ireland. Freshwater Crayfish, 4, 215-220.

SÁEZ-ROYUELA M., CARRAL J.M., CELADA J.D., MUÑOZ C., PÉREZ J.R., 1995. Effects of management on survival and growth of stage 2 juvenile freshwater crayfish (Pacifastacus leniusculus Dana) under laboratory conditions. Aquaculture, 133, 123-133.

SÁEZ-ROYUELA M., CARRAL J.M., CELADA J.D., PÉREZ J.R., 2001. Effects of shelter type and food supply frequency on survival and growth of stage-2 juvenile white-clawed crayfish (Austropotamobius pallipes Lereboullet) under laboratory conditions. Aquaculture International, 9, 489-497.

SMITH G.R.T., LEARNER M.A., SLATER F.M., FOSTER J., 1996. Habitat features important for the conservation of the native crayfish Austropotamobius pallipes in Britain. Biological Conservation, 75, 239-246.

STEIN R.A., 1977. Selective predation, optimal foraging, and the predator-prey interaction between fish and crayfish. Ecology, 58, 1237-1253.

STEIN R.A., MAGNUSON J.J., 1976. Behavioral response of crayfish to a fish predator. Ecology, 57, 751-761.

TAUGBØL T., SKURDAL J., 1992. Growth, mortality and moulting rate of noble crayfish Astacus astacus L. juveniles in aquaculture experiments. Aquaculture and Fisheries Management, 23, 411-420. 